\title{
IMPLEMENTASI METODE TAMI OTAKA DALAM PEMBELAJARAN HAFALAN AL-QUR'AN DI TK PINTAR KOTA BANDUNG
}

\author{
Muhammad Sufyan As-Tsauri \\ Pascasarjana UIN Sunan Gunung Djati Bandung \\ sufyancrb@gmail.com
}

\section{Abstract}

The purpose of this research is to see the implementation, evaluation, and advantages and disadvantages of the Tami Otaka Method. The Tami Otaka Method is a method of memorizing by using the ability of the right brain by means of the students memorizing the Qur'an while moving their hands from the verse they are reading. The type of research taken is field research using a qualitative approach. The object of this research is TK PINTAR Bandung, which includes the principal, tahfidz teacher, curriculum, and students. To obtain research data, researcher used observation, interview, and documentation techniques. This research uses descriptive qualitative analysis, so that the results of this study are manifested in the form of words both orally and verbally. The results obtained are as follows: first, to achieve purpose of the learning, TK PINTAR Bandung uses the Tami Otaka method with the help of audio, visual, audio-visual and body movements of a teacher. Second, the curriculum used is a synthesis of the National Curriculum and the Typical Curriculum of TK PINTAR Bandung. Third, learning is carried out in groups. Fourth, the evaluation is given continuously everyday and there is also an evaluation every semester.

Keywords: Lerning, Memorizing Qur'an, Tami Otaka Method, TK PINTAR Bandung

\section{Abstrak}

Tujuan dari penelitian ini adalah untuk mengetahui pelaksanaan, penerapan, evaluasi serta kelebihan dan kekurangan dari Metode Tami Otaka. Metode Tami Otaka adalah Metode menghafal menggunakan 
kemampuan otak kanan dengan cara siswa menghafal AlQur'an sambil menggerakkan tangan dari arti ayat yang dibaca. Jenis penelitian yang diambil adalah penelitian lapangan dengan menggunakan pendekatan kualitatif. Objek penelitian ini adalah lembaga TK PINTAR Bandung yang di dalamnya ada kepala sekolah, guru tahfidz, kurikulum, dan siswa. Untuk memperoleh data penelitian, peneliti menggunakan teknik observasi, wawancara, dan dokumentasi. Penelitian ini menggunakan analisis kualitatif deskriptif, sehingga hasil dari penelitian ini diwujudkan dalam bentuk kata-kata baik tulisan maupun lisan. Hasil penelitian diperoleh sebagai berikut: pertama, untuk mencapai tujuan pembelajaran, TK PINTAR Bandung menggunakan metode Tami Otaka dengan dibantu media auido, visual, audio-visual dan gerakan tubuh dari seorang guru. Kedua, kurikulum yang digunakan sintesis dari kurikulum Nasional dan kurikulum khas TK PINTAR Bandung. Ketiga, pembelajaran dilakukan secara berkelompok. Keempat, evaluasi diberikan terus menerus setiap harinya dan ada juga evaluasi tiap semester.

Kata Kunci: Pembelajaran, Tahfidz Al-Qur'an, Metode Tami Otaka, TK PINTAR Bandung

\section{PENDAHULUAN}

Al-Qur'an diturunkan untuk semua bangsa dan di dalamnya tidak tercampur dengan kebatilan. Kondisi bangsa Arab saat diturunkannya Al-Qur'an saat itu mayoritas masih buta huruf dan mereka tidak menganggap catatan sebagai suatu hal yang penting. Model yang mereka gunakan dalam menyimpan informasi adalah hafalan yang pada akhirnya hafalan menjadi tolok ukur kecerdasan seseorang. ${ }^{1,2}$

Seiring berjalannya waktu, usaha-usaha pemeliharaan Al-Qur'an terus dilakukan dari generasi ke generasi berikutnya,

${ }^{1}$ Mana Khalil Qattan, Studi Ilmu-Ilmu Qur'an (Bogor: Litera Antar Nusa, 2008).

${ }^{2}$ Ahmad Sudrajat, "Al-Qur'an Dalam Perspektif Budaya," HUMANIKA (2009): 1. 
salah satunya dengan cara menghafal Al-Qur'an. Al-Hafidz menyebutkan bahwa menghafal Al-Qur'an penting dilakukan karena beberapa alasan sebagai kerikut: Pertama, Al-Qur'an diturunkan, diterima dan diajarkan kepada Nabi secara hafalan. Kedua, Al-Qur'an diturunkan secara berangsur-angsur merupakan isyarat dan dorongan betapa pentingnya menghafal. Ketiga, menghafal Al-Qur' an hukumnya fardhu kifayah.

Selain ketiga urgensi menghafal Al-Qur'an di atas, setiap orang hendaknya memanfaatkan usia paling berharga dalam menghafal yaitu usia anak-anak. Pada usia ini daya tangkap pada ayat yang dihafal akan tertanam kuat. Namun metode pengajaran yang digunakan oleh guru di berbagai pondok pesantren, masjid-masjid, maupun rumah-rumah dirasa membosankan, tidak sesuai dengan kondisi perkembangan anak, sehingga memakan waktu yang lama untuk mencapai target hafalan.

Dalam Jurnal Pendidikan Anak Usia Dini menyebutkan bahwa agar anak mencapai perkembangan yang optimal, maka metode pembelajaran, media, dan alat peraga yang digunakan oleh guru merupakan faktor yang berperan langsung dalam proses pembelajaran. Dalam hal ini ketepatan metode dan motivasi yang tinggi akan mempercepat proses pencapaian dan pemahaman terhadap materi pembelajaran tersebut.

Adapun upaya untuk mencapai tujuan pembelajaran yang optimal, metode yang tepat harus diimplementasikan dalam pembelajaran. Secara sederhana implementasi pembelajaran dapat diartikan sebagai pelaksanaan pembelajaran. Secara garis besar, implementasi pembelajaran merupakan suatu tindakan dari sebuah rencana yang telah disusun secara matang dan terperinci dalam melakukan proses pembelajaran. ${ }^{3}$

TK PINTAR Bandung sebagai lembaga formal yang menyelenggarakan program tahfidz Al-Qur'an bagi anak usia dini memiliki metode menyenangkan sesuai dengan perkembangan anak. Metode yang dimaksud adalah Metode Tami Otaka yang mana guru dalam proses mengajar menggunaan isyarat tangan sebagai gambaran arti dari ayat yang

${ }^{3}$ Usman, Manajemen Teori, Praktik, Dan Riset Pendidikan (Jakarta: Bumi Aksara, 2011). 
sedang dihafal yang kemudian dibacaan kisah berkaitan dengan surat/ayat yang sedang dihafal.

Penelitian ini termasuk penelitian lapangan yang bersifat deskriptif kualitatif, bertujuan untuk mengetahui impelementasi pembelajaran tahfidz Al-Qur'an menggunakan metode Tami Otaka di TK PINTAR Bandung. Subjek dalam penelitian ini yaitu semua yang menjadi sumber data dalam penelitian yaitu guru tahfidz, kepala sekolah, waka kurikulum, founder metode Tami Otaka, serta siswa dan orang Tua siswa. Metode yang digunakan dalam penelitian ini yaitu wawancara, observasi, dan studi dokumentasi. Wawancara yang dipakai ialah wawancara terpimpin dengan menggunakan pedoman wawancara yang sudah disiapkan baik untuk guru tahfidz, siswa, kepala sekolah, founder metode Tami Otaka, maupun pertanyaan untuk orang tua siswa. Dalam penelitian ini dilakukan Triangulasi dimana dokumen-dokumen yang ada seperti buku pegangan Guru dan Siswa, standar proses pembelajaran, kurikulum semuanya dicek dan dikomparasikan dengan hasil wawancara dan observasi. Metode ini digunakan untuk mendapatkan bagaimana gambaran proses pembelajaran tahfidz menggunakan metode Tami Otaka serta kelebihan dan kekurangannya.

Melihat permasalahan di atas dan keunikan yang ada pada metode Tami Otaka, maka peneliti memilih metode Tami Otaka sebagai kajian penelitian karena dalam pembelajarannya terdapat aktivasi otak kanan anak-anak ketika menghafal AlQur'an yang mana jarang sekali ditemukan di lembaga tahfidz Al-Qur'an lainnya. Metode Tami Otaka diprediksi mampu membuat anak-anak senang dalam menghafal Al-Qur'an dan membekas dalam ingatan. Tujuan dari penelitian ini adalah untuk mengetahui pelaksanaan, penerapan, evaluasi serta kelebihan dan kekurangan dari Metode Tami Otaka.

\section{Pembahasan}

Berdasarkan hasil observasi, wawancara, dan studi dokumentasi yang telah peneliti lakukan di TK PINTAR Bandung, maka dalam pembahasan ini akan dilakukan analisis dari temuan di lapangan berkaitan dengan metode Tami Otaka, penerapan metode Tami Otaka dari mulai perencanaan, pelaksanaan, dan evaluasi. Terakhir dalam pembahasan ini 
dianalisis juga mengenai kelebihan dan kekurangan dari metode Tami Otaka. Adapun analisis hasil penelitian dapat diuraikan sebagai berikut:

\section{Metode Tami Otaka}

Metode untuk menghafal Al-Qur'an sudah banyak digunakan di setiap lembaga yang memiliki program untuk menghafal Al-Qur'an, yaitu Lembaga Tahidz Al-Qur'an. Tahfidz berasal dari bahasa Arab dari kata يُ نَفَفّظ فَّyang mempunyai arti menghafal atau usaha terus menerus dan berulang-ulang untuk meresapkan Al-Qur'an ke dalam pikiran dengan sengaja, sadar dan sungguh-sungguh agar selalu ingat, sehingga dapat mengungkapkan kembali di luar kepala. ${ }^{4}$ Metode untuk menghafal Al-Qur'an sudah banyak digunakan di setiap lembaga yang memiliki program untuk menghafal Al-Qur'an, yaitu Lembaga Tahidz Al-Qur'an. Tahfidz berasal dari bahasa Arab dari kata يُ نَحَفّظ فًََّ dan berulang-ulang untuk meresapkan Al-Qur'an ke dalam pikiran dengan sengaja, sadar dan sungguh-sungguh agar selalu ingat, sehingga dapat mengungkapkan kembali di luar kepala. ${ }^{5}$

Metode dapat diartikan sebagai suatu cara menyampaikan nilai dari guru ke murid ${ }^{6}$ guna mencapai tujuan yang telah ditentukan. ${ }^{7}$ Dari hasil wawancara disebutkan bahwa metode Tami Otaka bertujuan untuk menyampaikan pesan ayat yang dihafal yaitu ayat-ayat dalam juz 30, bahkan mampu menghafal redaksi ayat hingga tertanam kuat di dalam otak anak. $^{8}$

Salah satu usaha yang tidak pernah ditinggalkan seorang guru adalah memahami kedudukan metode sebagai salah satu

${ }^{4}$ Hidayah, "Strategi Pembelajaran Tahfidz Al-Qur'an Di Lembaga Pendidikan," Taalum: Jurnal Pendidikan Islam 4 (2016): 65.

${ }^{5}$ lbid.

${ }^{6}$ Syahidin, Menelusuri Metode Pendidikan Islam Dalam Al-Qur'an (Bandung: CV. Alfabeta, 2009): 43.

${ }^{7}$ Departemen Pendidikan Nasional, Kamus Besar Bahasa Indonesia (Jakarta: Balai Pustaka, 2005).

${ }^{8}$ Rahmat Hidayat, Wawancara 
komponen yang merupakan faktor penunjang keberhasilan kegiatan belajar mengajar. ${ }^{9}$ Apabila materi dan metode pendidikan yang disampaikan dalam Al-Qur'an dapat disampaikan secara utuh oleh para pendidik masa kini, maka sangat memungkinkan untuk dapat menghasilkan suatu generasi yang tangguh dan berkualitas pada masanyasebagaimana generasi sahabat yang dibina langsung oleh Rasulullah Saw.

Pada masa itu, para sahabat memiliki kompetensi unggul untuk mengkaji ayat-ayat Al-Qur'an. Mereka belum mau menghafal dan menerima ayat baru sebelum ayat yang lama diaplikasikan dalam kehidupan sehari-hari. Tahfidz Al-Qur'an merupakan upaya strategis untuk membangun umat manusia. Karena itu, pembelajaran tahfidz memerlukan metode yang baik dalam pelaksanaannya, dikelola dengan baik dari segi kualitas maupun kuantitasnya. Hal tersebut bisa dicapai apabila siswa dapat menyelesaikan hafalan dengan memperoleh hasil belajar yang baik dan sesuai dengan target yang ingin dicapai.

Hasil belajar siswa ditentukan oleh berbagai faktor yang mempengaruhi salah satunya adalah metode. Dalam hal ini program tahfidz Al-Qur'an harus memiliki komponen yang terlibat di dalamnya dan guru harus menggunakan metode mengajar yang lebih memperhatikan perkembangan emosional siswa dalam proses pembelajaran tahfidz Qur'an. Perkembangan emosi menurut Hurlock bergantung pada faktor kematangan dan faktor belajar. ${ }^{10}$ Pembelajaran tahfidz metode Tami Otaka berusaha mengaktifkan otak kanan siswa dengan mendengar dan melihat audio 5 fokus ayat, mewarnai ayat menggunakan krayon, melihat gerakan tangan guru, sehingga ayat-ayat yang dihafal terimajinasi dalam akal anak dengan durasi yang lama. Hal tersebut sesuai dengan apa yang dikatakan Woolfolk yang mengatakan bahwa fungsi otak kanan berkaitan erat dengan

${ }^{9}$ Djaramah, Guru Dan Anak Didik Dalam Interaksi Edukatif (Jakarta: Rineka Cipta, 2006): 72.

${ }^{10}$ Umi Latifa, "Aspek Perkembangan Pada Anak Sekolah Dasar: Masalah Dan Perkembangannya," Academica: Journal of Multidisciplinary Studies 1, no. 2 (2017). 
kegiatan imajinatif seperti melukis, bermain musik, dan kerajinan tangan. ${ }^{11}$

Penggunaan otak kanan dan media visual sangat membantu siswa dalam mengingat ayat yang dihafal, sesuai dalam jurnal yang dibuat Sri, ${ }^{12}$ bahwa kemampuan otak kanan sangat penting ditingkatkan untuk keberhasilan anak di masa depan. Hasil penelitian mutakhir di AS menyebutkan, peran logika dalam membuat orang menjadi sukses hanya 4-6\%, sedangkan $94-96 \%$ adalah tanggungjawab otak kanan yang banyak berhubungan denganinovasi, kreativitas, naluri, intuisi, daya cipta, kejujuran, keuletan, tanggungjawab, kesungguhan, spirit, kedisiplinan, etika, empati dan lain-lain. Sedangkan tugas otak kiri adalah yang selalu berhubungan dengan angka-angka, bahasa, analisa, logika, intelektual, ilmu pengetahuan.

Setiap harinya, pembelajaran tahfidz metode Tami Otaka berfokus pada 5 ayat. ${ }^{13}$ Hal tersebut menurut para tahfidz tidak terlalu berat bagi anak-anak untuk menghafalnya. Hal tersebut sesuai dengan apa yang Rasulullah praktekkan saat mendidik para sahabat yaitu menggunakan langkah-langkah sistematis, Pertama, Rasulullah memperhatikan tahapan belajar. Materi diberikan sedikit demi sedikit hingga materi yang beliau ajarkan dapat dipahami dengan mudah. Kedua, pengajaran dilakukan dengan memperhatikan situasi dan kondisi. Ketiga, Rasulullah mengajar disesuaikan dengan kemampuan peserta didik. ${ }^{14}$ Pada dasarnya dalam proses pembelajaran masa kini, pasti ditemukan siswa yang memiliki masalah dalam belajar.

${ }^{11}$ Ibid.

${ }^{12}$ Idha Ayu Sri Widhiyani, "Penerapan Penggunaan Media Permainan Fantasi Dan Imajinatif Kreatif Untuk Meningkatkan Kemampuan Otak Kanan Dan Mengembangkan Kemampuan Berbahasa," E-Journal Pascasarjana Universitas Pendidikan Ganesha 4 (2014): 9.

${ }^{13}$ Dedeh Sumiati, Wawancara

${ }^{14} \mathrm{Al}-$ Fattah, 40 Strategi Pembelajaran Rasulullah (Yogyakarta: Tiara Wacana, 2015): 70-80. 
Berikut contoh metode menghafal Tami Otaka yang terdapat dalam buku Belajar Menghafal Al-Qur'an Metode Khas Otak Kanan pada surat Al-Tariq ayat 11: ${ }^{15}$

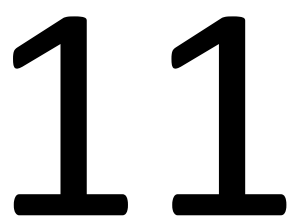

9.

10.

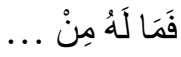

11.

\begin{tabular}{|l|l|l|l|l|}
\hline 11 & 11 & 11 & 11 & 11 \\
\hline 11 & 11 & 11 & 11 & 11 \\
\hline
\end{tabular}

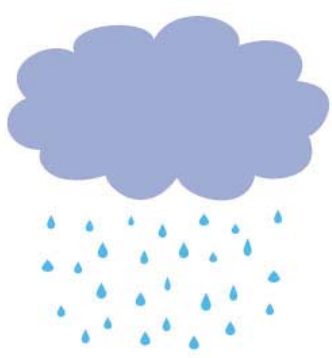

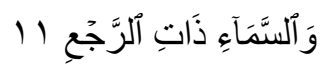

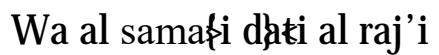

Demi langit yang mengandung hujan

Gambar 1. Konten Buku Khas Metode Tami Otaka

Sebelum memulai menghafal suatu ayat, siswa diminta mengamati ayat yang akan dihafal beserta gambar dan gerakan dari seorang pendidik. Pendidik melakukan gerakan kreatif sesuai dengan arti ayat ketika mengajarkan pada siswa. Gambar yang disajikan dalam buku dibuat sesuai dengan terjemahan suatu ayat. Tiga buah potongan ayat disisi kiri berfungsi membantu siswa apabila lupa menyebutkan dua ayat sebelumnya. Angka 11 berjumlah sepuluh seperti pada tabel diatas mengambarkan banyaknya pengulangan yang dilakukan oleh siswa dalam menghafal suatu ayat. Ketika siswa baru mengulang 1 kali pada ayat yang sedang dihafal, maka siswa mencoret 1 kolom dari 10 kolom yang tersedia. Selain penggunaan buku di atas, siswa juga diminta mengamati sebuah tayangan yang ditampilkan melalui LCD Proyektor berkaitan

${ }^{15}$ Rahmat Hidayat, Belajar Menghafal Al-Qur'an Metode Khas Otak Kanan (Bandung: Pustaka Pintar, 2015). 
dengan makna ayat yang dihafal. Media LCD Proyektor bisa digunakan dalam proses pembelajaran karena dapat meningkatkan kreatifitas siswa. ${ }^{16}$

Metode Tami Otaka menuntut kebiasaan yang disebut QAHS (Quantum Audio Habit System) berupa audio yang harus diputar selama di sekolah dan di rumah. Siswa dibiasakan setiap harinya menghafal dalam berbagai kondisi seperti bermain sambil menghafal dan mendengarkan audio 5 fokus ayat dan makan sambil mendengarkan audio ayat yang dihafal. Pembiasaan menjadi aspek penting dalam tujuan pembelajaran hafalan Al-Qur'an. Pengetahuan dan keterampilan menghafal yang siswa kuasai dari ayat-ayat Al-Qur'an tidak berhenti pada taraf sekadar tahu atau terampil menghafal saja. Kondisi itu harus dilanjutkan dengan proses pembiasaan agar apa yang telah diketahui dan kuasai tidak dilupakan. ${ }^{17,18,19}$

\section{Perencanaan Pembelajaran Hafalan Al-Qur'an dengan Menggunakan Metode Tami Otaka}

Dari hasil wawancara dengan bu Dedeh selaku guru tahfidz, beliau mengatakan bahwa sehari sebelum mengajar selalu menghafal kembali ayat yang akan diajarkan kepada siswa termasuk gerakannya. Hal itu sesuai dengan tugas sebagai seorang pendidik yaitu merencanakan pembelajaran, sesuai dengan UU Sistem Pendidikan Nasional No. 20 Tahun 2003 Bab XI tentang Pendidik dan Tenaga Kependidikan pasal 2 menjelaskan bahwa pendidik merupakan tenaga profesional yang bertugas merencanakan dan melaksanakan proses pembelajaran, menilai hasil pembelajaran, melakukan pembimbingan dan pelatihan, serta melakukan penelitian dan

16 Mulyono and Ilham Ampo, "Pemanfaatan Media Dan Sumber Belajar Abad 21," Paedagogia: Jurnal Pendidikan 9, no. 2 (2021): 93-112.

${ }^{17}$ Abdullah Luthfi, Pembelajaran Al-Qur'an Dan Hadis (Jakarta: Departemen Agama, 2009).

${ }^{18}$ Sanjaya, Strategi Pembelajaran Berorientasi Proses Pendidikan (Jakarta: Kencana, 2008).

19 Nur Arofah, "Implementasi Teori Behaviorisme Terhadap Pembiasaan Membaca Asmaul Husna," Paedagogia: Jurnal Pendidikan 8, no. 1 (2019): 177. 
pengabdian kepada masyarakat, terutama bagi pendidik pada perguruan tinggi. ${ }^{20}$

Pendidik melakukan wudhu terlebih dahulu sebelum mengajar. Hal tersebut akan membuat badan suci dan bersih serta hati menjadi tenang. Peneliti mengamati guru setelah berwudhu, mereka kemudian membaca doa menuntut ilmu kemudian mendata siswa yang telah hadir. Guru di TK Pintar adalah sekaligus wali kelas bagi siswa yang mereka ajar. Secara administratif, pengelolaan kehadiran dan ketidakhadiran siswa pada tingkat kelas menjadi tanggung jawab wali kelas. oleh karena itu, wali kelas seharusnya dapat mendata secara akurat tingkat kehadiran dan ketidakhadiran siswa di kelas yang menjadi tanggung jawabnya sekaligus dapat menganalisis dan menyajikan dalam bentuk grafik atau tabel. ${ }^{21}$

Selain guru, siswa juga melakukan perencanaan sebelum mereka belajar seperti berwudhu sebelum menghafal Al-Qur'an, membaca do'a akan belajar, dan menyiapkan hafalan yang akan disetorkan kepada guru. Ra'uf memandang berdo'a saat menghafal Al-Qur'an adalah amalan yang tidak saja harus dilakukan setiap hari, namun juga harus intensif. ${ }^{22}$

Dari hasil wawancara dengan pak Yayan selaku guru siswa kursus TK Pintar mengatakan bahwa hafalan yang tidak lancar akan disetorkan kembali dipertemuan selanjutnya agar siswa benar-benar hafal terhadap suatu ayat, sesuai dengan metode lain bernama takrir bahwa mengulang hafalan atau mensima'-kan (memperdengarkan) hafalan yang pernah dihafal itu penting agar tetap terjaga dengan baik. Selain dengan guru, takrir juga dilakukan secara individu dengan maksud untuk melancarkan hafalan yang telah dihafal, sehingga tidak mudah lupa. $^{23}$

${ }^{20}$ Departemen Pendidikan Nasional, Undang-Undang Nomor 20 Tahun 2003 (Jakarta: Depdiknas, 2003).

${ }^{21}$ Direktorat Tenaga Kependidikan, Administrasi Dan Pengelolaan Sekolah (Jakarta: Direktorat Tenaga Kependidikan, 2008).

${ }^{22}$ Rauf, Anda Pun Bisa Menjadi Hafidz Al-Qur'an: 97.

${ }^{23}$ Hidayah, "Strategi Pembelajaran Tahfidz Al-Qur'an Di Lembaga Pendidikan.": 74 


\section{Pelaksanaan Pembelajaran Hafalan Al-Qur'an dengan Menggunakan Metode Tami Otaka}

Dalam metode tahfidz Al-Qur'an, interaksi peserta didik dengan pendidik lebih bersifat formal dan terstruktur, serta memberikan pelajaran sedikit demi sedikit agar peserta didik tidak merasa berat memahaminya, sehingga munculah gagasan silabus dan kurikulum untuk sekolah-sekolah. Pelaksanan pembelajaran hafalan Al-Qur'an mengacu pada kurikulum yang telah disusun oleh tim kurikulum yaitu bu Dwi dan bu Dedeh. Adapun pelaksanaan pembelajaran meliputi kegiatan awal, kegiatan inti, dan kegiatan akhir.

Menurut bu Dedeh selaku tim kurikulum sekaligus guru tahfidz di TK PINTAR Bandung, kegiatan awal dalam pembelajaran dilakukan dengan cara membangun semangat para peserta dalam belajar, membaca do'a sebelum belajar, mengetahui 5 fokus ayat apa saja yang akan mereka hafal, sehingga mereka terfokuskan untuk belajar, mengulang kembali pelajaran yang sudah diberikan pada pertemuan kemarain serta adanya pemberian motivasi dari guru untuk memacu semangat belajar para peserta. Hasil penelitian yang dilakukan Qudsi menunjukkan bahwa pengajaran hendaknya dapat menarik minat siswa, tahapan awal dari proses pengajaran hendaklah dimulai dengan usaha membangkitkan minat tersebut. ${ }^{24}$ Minat harus dijaga dan terus dikembangkan selama proses pengajaran berlangsung, karena mudah sekali berkurang atau hilang selama proses pengajaran berlangsung.

Cara yang dilakukan guru tahfidz di TK PINTAR Bandung dalam memulai pembelajaran sesuai dengan standar proses pembelajaran tahfidz pada umumnya yaitu 1) menghafal dengan niat ikhlas karena Allah, ${ }^{25}$ 2) memperbanyak do'a untuk menghafal Al-Qur'an, ${ }^{26} 3$ ) menentukan salah satu metode untuk

${ }^{24}$ Qudsi, "Pengaruh Metode Pembelajaran Kooperatif (Cooperative Learning) Dan Motivasi Belajar Terhadap Prestasi Belajar Siswa SMA," Proyeksi 6 (2011): 38.

${ }^{25}$ Sa'dullah, 9 Cara Praktis Menghafal Al-Qur'an (Jakarta: Gema Insani Press, 2008): 29.

${ }^{26}$ Rauf, Anda Pun Bisa Menjadi Hafidz Al-Qur'an (Jakarta: Markaz Al-Qur'an, 2009): 97. 
menghafal Al-Qur'an, 4) memperbaiki bacaan, 5) menghafal kepada guru yang ahli dan mapan, 6) menggunakan satu jenis mushaf Al-Qur'an, 7) memilih waktu yang tepat untuk menghafal utamanya waktu sahur.

Kegiatan inti sebagai proses pembelajaran yang utama untuk pencapaian yang sudah ditetapkan dalam standar pengajaran metode Tami Otaka dengan menggunakan alat dan metode yang telah direncanakan, dilakukan secara interaktif, inspiratif, menyenangkan, menantang, dan memotivasi para peserta untuk berpartisipasi aktif, serta memberikan ruang yang cukup untuk mengembangkan kreativitas dan kemandirian para peserta sesuai dengan bakat, minat, serta perkembangan fisik mereka, sehingga anak didik atau pihak terdidik tidak menjadi korban ambisi orang tua atau lembaga pendidikan yang tidak mau memperhatikan bakat dan bawaan anak didik.

Kegiatan pembelajaran yang utama ini pun diiringi dengan sedikit canda dari guru, hal ini dilakukan agar para peserta tidak merasa jenuh dalam belajar dan tidak merasa bosan.Guru pun memberikan kesempatan kepada para peserta untuk bertanya tentang materi yang belum dipahami oleh mereka sebelum beranjak ke materi yang selanjutnya.

Kegiatan akhir dilakukan untuk mengecek hafalan siswa terhadap materi yang telah disampaikan oleh guru. Sebelum berakhirnya pertemuan, Peserta diberikan tindak lanjut berupa tugas atau Pekerjaan Rumah untuk mendengarkan audio 5 fokus ayat selanjutnya sebagai bahan hafalan pada pertemuan selanjutnya, serta meminta siswa untuk menghafal bagi yang belum lulus pada pertemuan tersebut, sesuai dalam buku Perencanaan Pengajaran yang ditulis oleh Nana Saodih bahwa guru dapat merancang kegiatan tindak lanjut yang perlu dilakukan baik berupa perbaikan bagi siswa-siswa tertentu, maupun berupa penyempurnaan program pembelajaran.

\section{Evaluasi Pembelajaran Hafalan Al-Qur'an dengan Menggunakan Metode Tami Otaka}

Evaluasi pembelajaran hafalan Al-Qur'an menggunakan metode Tami Otaka selalu dilakukan diakhir pertemuan pada setiap selesai sesi menghafal. Hal tersebut dilakukan untuk mengetahui apakah siswa sudah hafal 5 fokus 
ayat yang diajarkan atau belum. Guru meminta siswa untuk membacakan kembali 5 fokus ayat yang telah dihafal, kemudian siswa melafalkan hafalannya. Apabila siswa lupa, maka guru akan membantu siswa mengingatkan kata pada ayat yang dilupakan siswa. Selain hafalan ayat, kemampuan afektif dan psikomotor siswa juga dinilai oleh guru dengan mengecek hasil mewarnai siswa di buku masing-masing, juga sikap sosial dengan sesama. Hal ini perlu dilakukan karena evaluasi memang harus dilakukan secara komprehensif dari aspek kognitif, afektif, dan psikomotor. ${ }^{27}$

Ada 3 kategori nilai yang akan didapatkan siswa setelah dilakukan tes oleh guru. Kesatu hafal mandiri, jika siswa mampu membaca sendiri suatu ayat tanpa dipandu oleh guru. Guru memberi kode ' $M$ ' sebagai tanda mandiri pada buku nilai. Kedua hafal dibantu, jika siswa lupa kemudian mendapat bantuan dari guru ketika dites. Guru memberi kode ' $D$ ' sebagai tanda dibantu pada buku nilai. Ketiga tidak hafal, jika siswa sama sekali tidak bisa melafalkan apa yang telah diajarkan oleh guru. Guru memberi kode ' $T$ ' sebagai tanda siswa tidak hafal pada buku nilai. Siswa yang memperoleh nilai ' $D$ ' dan ' $T$ ', maka pertemuan selanjutnya harus perbaikan agar nilai mereka bisa menjadi ' $M$ ' atau hafal mandiri. ${ }^{28}$

Selain evaluasi harian dengan mengecek hafalan 5 fokus ayat, guru juga mengadakan evaluasi bulanan (monthly report) dan evaluasi persemester dengan mengecek hafalan 3 surat. Arifin menjelaskan bahwa evaluasi adalah usaha untuk mendapatkan nilai yang terdapat dalam proses belajar mengajar yang dilihat dari hasil yang dicapai oleh setiap siswa dalam jangka waktu tertentu misalnya penilaian harian, mingguan, bulanan, ujian tengah semester, dan ujian akhir semester. ${ }^{29}$ Berdasarkan hasil observasi peneliti, guru telah melakukan evalusi persemester dengan mengetes siswa untuk menunjukkan

${ }^{27}$ Ahmad Saifulloh and Imam Safi'i, "Evaluasi Pembelajaran Mata Pelajaran Pendidikan Agama Islam Di Sekolah Menengah Pertama (Studi Kasus Di SMPN 2 Ponorogo)," Jurnal Educan 1, no. 1 (2017).

${ }^{28}$ Wawancara dengan Pak Yayan Rusmana (Guru Kursus Tahfidz)

${ }^{29}$ Zainal Arifin, Evaluasi Pembelajaran (Bandung: PT Remaja Rosdakarya, 2012). 
hafalan surat Al-Ghasyiah, Al-Thariq, dan Al-A'la dengan hasil sebagai berikut:

\begin{tabular}{|c|l|c|c|c|c|}
\hline No & \multicolumn{1}{|c|}{$\begin{array}{c}\text { Nama } \\
\text { Surat }\end{array}$} & $\begin{array}{c}\text { Hafal } \\
\text { Mandiri }\end{array}$ & $\begin{array}{c}\text { Hafal } \\
\text { Dibantu }\end{array}$ & $\begin{array}{c}\text { Tidak } \\
\text { Hafal }\end{array}$ & Keterangan \\
\hline 1 & Al-Thariq & $41 \%$ & $59 \%$ & - & Lulus \\
\hline 2 & Al-A'la & $16 \%$ & $74 \%$ & $10 \%$ & Lulus \\
\hline 3 & $\begin{array}{l}\text { Al- } \\
\text { Ghasyiah }\end{array}$ & $27 \%$ & $73 \%$ & - & Lulus \\
\hline
\end{tabular}

Tabel 1. Hasil Evaluasi Persemester

\section{Kelebihan dan Kekurangan Metode Tami Otaka}

Dari hasil wawancara dengan bu Dedeh dan founder metodeTami Otaka ustadz Rahmat Hidayat serta mengamati guru ketika mengajar, peneliti dapat menyimpulkan bahwa kelebihan metode Tami Otaka adalah media dan metode sangat cocok dengan kondisi siswa usia taman kanak-kanak. Medianya sangat menyenangkan dengan adanya ilustrasi dan guru selalu menggunakan gerakan tangan, sehingga menarik perhatian siswa. Beberapa siswa bahkan merindukan kegiatan belajar untuk menebak gerakan seperti apa yang akan diajarkan selanjutnya oleh guru. Sedangkan kekurangan menggunakan metode Tami Otaka adalah gerakan yang tidak bebas ketika mengajarkan hafalan membuat guru terkadang lupa. Guru harus menghafal satu persatu gerakan yang beragam dari masingmasing ayat.

\section{Penutup}

Berdasarkan pembahasan di atas, didapatkan simpulan umum bahwa metode Tami Otaka berhasil dalam meningkatkan hafalan Al-Qur'an pada siswa. Adapun secara khusus simpulan penelitian ini sebagai berikut:

1) Persiapan untuk menghafal Al-Qur'an, dimana siswa melakukan permainan terlebih dahulu sebelum menghafal, berwudhu, shalat Dhuha, selanjutnya siswa berdo'a bersama-sama lalu mengulang kembali hafalan yang sudah dihafal. Para siswa bermain sebelum belajar guna menarik minat dan siap mendengarkan akan instruksi guru selanjutnya. Selain itu dengan berwudhu dan solat dhuha 
akan menenangkan jiwa dan pikiran para siswa, sehingga mempermudah siswa dalam menghafal ayat-ayat dalam juz 30 ;

2) Dalam pelaksanaan menghafal Al-Qur'an dengan menggunakan metode Tami Otaka di TK Pintar Bandung, para siswa melihat dan mendengarkan guru ketika mengajar hafalan dengan menggunakan media, lalu siswa memperagakan sesuai apa yang guru ajarkan. Penggunaan media audio, visual, dan audio-visual dalam proses pembelajaran merupakan cara guru dalam mengaktifkan imajinasi anak sekaligus bentuk pengulangan materi. Secara tidak sadar, pengulangan (tikrar) membuat siswa mampu mengingat ayat dengan durasi lama. Guru mengulang setiap ayat sebanyak 10 kali dengan variasi tempo dan suara yang berbeda. Guru menekankan kata disetiap akhir ayat agar siswa mengingat ciri khas setiap ayat. Selanjutnya siswa mewarnai gambar dibuku panduan hafalan;

3) Evaluasi dibagi menjadi tiga bagian. Pertama, evaluasi harian dengan cara mengetes siswa dari 5 fokus ayat yang telah dihafal secara lisan. Apabila siswa bisa membaca dengan lancar maka lulus, jika tidak maka hafalan yang belum lancar akan dites ulang dipertemuan selanjutnya. Cara tersebut merupakan program remedial untuk memperbaiki dan mencari tahu dimana letak kesulitan belajar pada siswa. Kedua, evaluasi bulanan berbentuk laporan bulanan yang dicatat dalam buku mentoring. Ketiga, evaluasi persemester yang diuji oleh wali kelas masing-masing. Surat yang diujikan pada evaluasi semester sebanyak 3 surat.

4) Metode Tami Otaka yang diterapkan di TK Pintar Bandung memiliki kelebihan yaitu bisa membuat siswa bahagia dalam menghafal Al-Qur'an dengan ragam media yang digunakan serta kemampuan individu seorang guru dalam mengolah emosi siswa. Namun Metode Tami Otaka juga masih mempunyai kekurangan seperti guru yang kadang lupa atas gerakan tangan yang sudah diajarkan pada pertemuan sebelelumnya. Hal ini terjadi karena guru lupa terhadap arti ayat yang sudah pernah diajarkan. 
Berdasarkan simpulan dari hasil peneitian dan pembahasan di atas, maka peneliti berencana untuk melakukan tindak lanjut dalam hal meneliti pengaruh bimbingan orang tua siswa di rumah dalam menyukseskan program menghafal juz 30 menggunakan metode Tami Otaka. Dari hasil penelitian ini terbukti dengan digunakannya ragam media khas metode Tami Otaka dan kemampuan seorang guru dalam menarik minat anak untuk menghafal, mampu meningkatkan hafalan Al-Qur'an. Namun faktanya, dari hasil evaluasi persemester, ada siswa yang memerlukan sedikit bantuan dari guru untuk bisa meneruskan suatu ayat, bahkan ada yang lupa sama sekali meskipun sudah diberi clue. Hal tersebut tentunya perlu diteliti apakah ada pengaruh bimbingan orang tua terhadap anak dalam menghafal juz 30 ketika anak sedang berada di rumah.

\section{Daftar Pustaka}

Al-Fattah. 40 Strategi Pembelajaran Rasulullah. Yogyakarta: Tiara Wacana, 2015.

Arifin, Zainal. Evaluasi Pembelajaran. Bandung: PT Remaja Rosdakarya, 2012.

Arofah, Nur. "Implementasi Teori Behaviorisme Terhadap Pembiasaan Membaca Asmaul Husna." Paedagogia: Jurnal Pendidikan 8, no. 1 (2019).

Djaramah. Guru Dan Anak Didik Dalam Interaksi Edukatif. Jakarta: Rineka Cipta, 2006.

Hidayah. "Strategi Pembelajaran Tahfidz Al-Qur'an Di Lembaga Pendidikan." Taalum: Jurnal Pendidikan Islam 4 (2016): 65.

Hidayat, Rahmat. Belajar Menghafal Al-Qur'an Metode Khas Otak Kanan. Bandung: Pustaka Pintar, 2015.

Kependidikan, Direktorat Tenaga. Administrasi Dan Pengelolaan Sekolah. Jakarta: Direktorat Tenaga 
Kependidikan, 2008.

Latifa, Umi. “Aspek Perkembangan Pada Anak Sekolah Dasar: Masalah Dan Perkembangannya." Academica: Journal of Multidisciplinary Studies 1, no. 2 (2017).

Luthfi, Abdullah. Pembelajaran Al-Qur'an Dan Hadis. Jakarta: Departemen Agama, 2009.

Mulyono, and Ilham Ampo. "Pemanfaatan Media Dan Sumber Belajar Abad 21." Paedagogia: Jurnal Pendidikan 9, no. 2 (2021): 93-112.

Nasional, Departemen Pendidikan. Kamus Besar Bahasa Indonesia. Jakarta: Balai Pustaka, 2005.

- Undang-Undang Nomor 20 Tahun 2003. Jakarta: Depdiknas, 2003.

Qattan, Mana Khalil. Studi Ilmu-Ilmu Qur'an. Bogor: Litera Antar Nusa, 2008.

Qudsi. "Pengaruh Metode Pembelajaran Kooperatif (Cooperative Learning) Dan Motivasi Belajar Terhadap Prestasi Belajar Siswa SMA.” Proyeksi 6 (2011): 38.

Rauf. Anda Pun Bisa Menjadi Hafidz Al-Qur'an. Jakarta: Markaz Al-Qur'an, 2009.

Sa'dullah. 9 Cara Praktis Menghafal Al-Qur'an. Jakarta: Gema Insani Press, 2008.

Saifulloh, Ahmad, and Imam Safi'i. "Evaluasi Pembelajaran Mata Pelajaran Pendidikan Agama Islam Di Sekolah Menengah Pertama (Studi Kasus Di SMPN 2 Ponorogo)." Jurnal Educan 1, no. 1 (2017).

Sanjaya. Strategi Pembelajaran Berorientasi Proses Pendidikan. Jakarta: Kencana, 2008.

Sudrajat, Ahmad. "Al-Qur'an Dalam Perspektif Budaya." HUMANIKA (2009): 1. 
Syahidin. Menelusuri Metode Pendidikan Islam Dalam AlQur'an. Bandung: CV. Alfabeta, 2009.

Usman. Manajemen Teori, Praktik, Dan Riset Pendidikan. Jakarta: Bumi Aksara, 2011.

Widhiyani, Idha Ayu Sri. "Penerapan Penggunaan Media Permainan Fantasi Dan Imajinatif Kreatif Untuk Meningkatkan Kemampuan Otak Kanan Dan Mengembangkan Kemampuan Berbahasa.” E-Journal Pascasarjana Universitas Pendidikan Ganesha 4 (2014): 9. 